\title{
Effect of Osmotic Pressure on the Production of Retroviral Vectors: Enhancement in Vector Stability
}

\author{
A.S. Coroadinha, ${ }^{1}$ A.C. Silva, ${ }^{1}$ E. Pires, ${ }^{1}$ A. Coelho, ${ }^{1}$ P.M. Alves, ${ }^{1}$ M.J.T. Carrondo ${ }^{1,2}$ \\ ${ }^{1}$ IBET/ITQB, Apartado 12, P-2781-901 Oeiras, Portugal; telephone: +351 2144277 87; \\ fax:+351214421161; e-mail: mjtc@itab.unl.pt \\ ${ }^{2}$ Laboratório de Engenharia Bioquímica, FCT/UNL, P-2825 Monte da Caparica, Portugal
}

Received 5 September 2005; accepted 19 December 2005

Published online 9 March 2006 in Wiley InterScience (www.interscience.wiley.com). DOI: 10.1002/bit.20847

\begin{abstract}
The use of Moloney murine leukaemia virus (MoMLV) derived retroviral vectors in gene therapy requires the production of high titer preparations. However, obtaining high titers of infective MoMLV retroviral vectors is difficult due to the vector inherent instability. In this work the effect of the cell culture medium osmotic pressure upon the virus stability was studied. The osmolality of standard medium was raised from 335 up to $500 \mathrm{mOsm} / \mathrm{kg}$ using either ionic (sodium chloride) or non-ionic osmotic agents (sorbitol and fructose). It was observed that, independently of the osmotic agent used, the infectious vector inactivation rate was inversely correlated with the osmolality used in the production media; therefore, the use of high medium osmolalities enhanced vector stability. For production purposes a balance must be struck between cell yield, cell productivity and retroviral stability. From the conditions tested herein sorbitol addition, ensuring osmolalities between 410 and $450 \mathrm{mOsm} / \mathrm{kg}$, yields the best production conditions; $\mathrm{NaCl}$ hampered the viral infectious production while fructose originates lower cell yields. Lipid extractions were performed for cholesterol and phospholipid analyses showing that more stable viral vectors had a $10 \%$ reduction in the cholesterol content. A similar reduction in cholesterol was observed in the producer cells. A detailed analysis of the major phospholipids composition, type and fatty acid content, by mass spectrometry did not show significant changes, confirming the decrease in the cholesterol to phospholipids ratio in the viral membrane as the major reason for the increased vector stability. (c) 2006 Wiley Periodicals, Inc.
\end{abstract}

Keywords: retroviral vectors; osmolality; stability; phospholipids; cholesterol; production

\section{INTRODUCTION}

Retrovirus mediated gene therapy offers several advantages over other gene transfer methods due to its high transduction efficiency, stable transgene integration and expression, and low immunogenicity (Mountain, 2000). However, the use of

\footnotetext{
Correspondence to: Dr. M.J.T. Carrondo

Contract grant sponsors: European Commission; Fundação para a Ciência e a Tecnologia-Portugal

Contract grant numbers: QLK3-CT-2002-01949; POCTI SFRHBD31282000
}

this vector in human gene therapy requires the production of large quantities of high infective titer stocks, which are very difficult to attain. For a single dose of therapeutic application, depending on the clinical protocol and disease, between $10^{7}$ and $10^{14}$ infectious viral particles are necessary (Davis et al., 1997; Dunbar and Kohn, 1996; Paul et al., 1993). The major obstacle for the production of high vector titers is its inherent instability and rapid loss of infectivity. The half-life of recombinant retrovirus derived from Moloney murine leukaemia virus (MoMLV) in cell culture medium at $37^{\circ} \mathrm{C}$ is low, ranging from 5 to $8 \mathrm{~h}$ (Higashikawa and Chang, 2001; Le Doux et al., 1999). The low stability of the vector leads to the accumulation of large amounts of non-infectious virus, thus reducing the vector transduction efficiency. Therefore, significant improvements in the current methodologies of production of retroviral vectors are required.

Several efforts have been made to improve the titer of retroviral vector preparations using diverse strategies like: (i) developing new packaging cell lines with improved productivities (Morita et al., 2000), (ii) establishing easy scalable cell suspension cultures (Pizzato et al., 2001), or (iii) using envelopes more resistant to shear stress, as the vesicular stomatitis virus G proteins (VSV-G) (Ory et al., 1996). The production process has also been the focus of a number of studies where the production parameters such as temperature, $\mathrm{pH}$, serum concentration and sugar-type source had high impacts on the final vector titers obtained (Cruz et al., 2000; Lee et al., 1996; McTaggart and Al-Rubeai, 2000; Merten, 2004). Different cell culture systems and bioreactor designs could also increase the production of MoMLV vectors (Merten, 2004; Merten et al., 2001a). Increasing the concentration of retrovirus after production has also been a strategy used to overcome the low titers of production (Lee et al., 1996; Paul et al., 1993).

Previous studies from our laboratory have shown an important increase in the intrinsic MoMLV retroviral vector stability when production was carried out at high concentrations of glucose or fructose (Coroadinha et al., 2006). Such high concentrations of sugars can have the drawback of leading to the production of high amounts of lactate. Since the use of high concentrations of sugars also increased 
medium osmolality, it was hypothesised that increased osmolality could constitute another strategy to improve the vector stability. The effect of the culture medium osmolality upon the viral vector stability and production is described in this study and compared with the use of high concentrations of fructose, a slow metabolised sugar (producing lower yields of lactate) that has previously been described as improving vector stability (Merten, 2004). Manipulation of the medium osmolality has been used extensively as a strategy to increase recombinant protein production in animal cell systems. The use of high osmotic pressure was first applied in hybridoma cells to improve the cell-specific antibody productivity (Cherlet and Marc, 1999). High osmolalities were also shown to improve recombinant protein production in Chinese Hamster Ovary (CHO) cells (Kim and Lee, 2002; Takagi et al., 2001). More recently hyperosmolality was applied to the production of recombinant proteins in insect cells by the baculovirus expression system, resulting in higher cellspecific productivities (Olejnik et al., 2003).

The recombinant retrovirus is composed of $2 \%$ RNA, $62 \%$ protein and $36 \%$ lipid (Andreadis et al., 1999). Thus, the lipid viral membrane is an important part of the virus composition and the viral membrane fluidity has been shown to be correlated with the retrovirus stability and infectivity (Beer et al., 2003; Cruz et al., 2005; Harada et al., 2005). Therefore, this manuscript analyses the membrane phospholipid and cholesterol composition of the retroviral vectors produced in media with different osmolytes and osmolalities and correlates it with the vector stability.

\section{MATERIALS AND METHODS}

\section{Cell Lines and Cell Culture Medium}

Te Fly A7 is an established retroviral producer cell line yielding MoMLV derived recombinant retroviral vectors expressing an amphotropic envelope and harbouring a MFGnlsLacz transgene as described elsewhere (Cosset et al., 1995). HCT-116 cell line (ATCC CCL-247) was used as the target cell to titrate infectious retroviral particles. Both cell lines were maintained in DMEM (Gibco, Paisley, UK) supplemented with $10 \%$ (v/v) Foetal Bovine Serum (FBS) (Gibco), $25 \mathrm{mM}$ of glucose (Sigma, St. Louis, MO) and 6 of $\mathrm{mM}$ glutamine (Gibco) in an incubator with an humidified atmosphere of $5 \% \mathrm{CO}_{2}$ air and maintained at $37^{\circ} \mathrm{C}$.

\section{Cell Number and Cell Size}

Cell concentration, viability and cell size was determined using $\mathrm{CASY}^{\circledR} 1$, Shärfe System GmbH (Reutlingen, Germany).

\section{Osmolality Effect on Vector Production and Stability}

To evaluate the effect of the osmolality on viral production, DMEM (Gibco) was supplemented with $10 \%$ (v/v) FBS (Gibco), glutamine at $6 \mathrm{mM}$ (Gibco), glucose at $25 \mathrm{mM}$ (335 $\mathrm{mOsm} / \mathrm{kg}$ ) (Sigma) and either sodium chloride (Merck,
Darmstadt, Germany) or sorbitol (Sigma) were added to adjust the medium osmolality to 410,450 and $500 \mathrm{mOsm} / \mathrm{kg}$. For fructose media supplementation, fructose (Sigma) was used, instead of glucose, at several concentrations corresponding to the different osmolalities without the addition of any further osmotic agent. Medium osmolalities were determined by the measurement of the depression of the freezing point using an osmometer (Roebling, Berlin, Germany). Cells were seeded in duplicates at $1 \times 10^{4}$ cells/ $\mathrm{cm}^{2}$ in $25 \mathrm{~cm}^{2}$ T-flasks with $5 \mathrm{~mL}$ of culture medium and incubated in a $\mathrm{CO}_{2}$ incubator at $37^{\circ} \mathrm{C}$. After 4 days the medium was replaced by fresh medium with the appropriate composition and cell concentration was determined. The next day the viral supernatant was harvested and filtered at $0.45 \mu \mathrm{m}$ for assessment of virus production and cell concentration. The retroviral vector decay kinetics and stability study was initiated by $1 / 10$ dilution of the viral supernatant in DMEM without any sugar or osmotic agent (corresponding to viral infectious titers between 1 and $3 \times 10^{6}$ i.p./mL for all samples except for the fructose $25 \mathrm{mM}$ experiment where, due to the low production, a $0.7 \times 10^{6}$ i.p. $/ \mathrm{mL}$ initial concentration was used). The viral suspension was incubated at $37^{\circ} \mathrm{C}$ in a $\mathrm{CO}_{2}$ incubator and samples were taken at $0,3,6,9$, 12, 24, 36 and $48 \mathrm{~h}$ after the viral decay kinetic study started and stored at $-85^{\circ} \mathrm{C}$ until the viral titer was determined. The experience was repeated at least three times using independent cell batches. Each experiment was performed using quadruplicates. The vector half-life was determined by fitting the data to the equation $V / V_{0}=\mathrm{e}^{-\gamma \mathrm{t}}$ (Le Doux et al., 1999). To evaluate the effect of different osmolalities and different osmolytes a two-way ANOVA statistical analysis was performed. Differences were considered significant when $P<0.05$.

\section{Measurement of Retrovirus Titer}

For the Infectious Particle titration HCT116 cells were seeded at $5 \times 10^{4}$ cells $/ \mathrm{cm}^{2}$ in 96 -well plates using DMEM (Gibco) supplemented with 10\% (v/v) FBS (Gibco), $4.5 \mathrm{~g} / \mathrm{L}$ of glucose (Sigma) and $6 \mathrm{mM}$ of glutamine (Gibco) and incubated overnight in a $\mathrm{CO}_{2}$ incubator at $37^{\circ} \mathrm{C}$. The next day the supernatant was removed and cells were infected in quadruplicates with $50 \mu \mathrm{L}$ of viral suspension at several viral dilutions performed in the supplemented DMEM containing $8 \mu \mathrm{g} / \mathrm{mL}$ of polybrene (Sigma). To enhance virus attachment, cells were incubated at $37^{\circ} \mathrm{C}$ for $4 \mathrm{~h}$ after which $150 \mu \mathrm{L}$ of fresh supplemented DMEM was added and cells were further incubated. Two days after infection, cells were fixed, medium was removed, and cells were washed with phosphate buffer saline (PBS) and incubated with formaldehyde (Merck) at $0.3 \%$ and glutaraldehyde (Sigma) at $1.35 \%$ in PBS for 5 min. After washing with PBS, staining was carried out with a solution of $0.2 \mathrm{mg} / \mathrm{mL}$ x-gal (5-bromo-4-chloro-3-indolyl- $\beta$ D-galactopyranoside) (Stratagene, La Jolla, CA), $5 \mathrm{mM}$ $\mathrm{K}_{3} \mathrm{Fe}(\mathrm{CN})_{6}$ (Merck), $5 \mathrm{mM} \mathrm{K}{ }_{4} \mathrm{Fe}(\mathrm{CN})_{6}$ (Merck), $1 \mathrm{mM}$ $\mathrm{MgCl}_{2}$ (Merck) in PBS. The viral titer was determined by counting the stained blue cells using a phase contrast inverted microscope and multiplying by the dilution factor. 


\section{Lipid Extractions From Producer Cells and Viral Vectors}

To assess the osmolality effect on the lipid cellular and viral composition DMEM (Gibco) was supplemented with $10 \%$ (v/v) FBS (Gibco), glutamine at $6 \mathrm{mM}$ (Gibco), and either glucose only at $25 \mathrm{mM}(335 \mathrm{mOsm} / \mathrm{kg})$ (Sigma) or fructose only at $140 \mathrm{mM}(450 \mathrm{mOsm} / \mathrm{kg})$ (Sigma) or glucose $25 \mathrm{mM}$ (Sigma) with sorbitol at $137 \mathrm{mM}(450 \mathrm{mOsm} / \mathrm{kg})$ (Sigma). Cells were seeded at $1 \times 10^{4}$ cells $/ \mathrm{cm}$ in $175 \mathrm{~cm}^{2}$ T-flasks with $35 \mathrm{~mL}$ of culture medium and incubated in a $\mathrm{CO}_{2}$ incubator at $37^{\circ} \mathrm{C}$. After 4 days, when cells reached $60 \%$ confluence, fresh medium replacement was carried out maintaining the original conditions. The next day the cells were harvested and cell concentration was determined; $7 \times 10^{7}$ cells were used to perform the Bligh and Dyer lipid extraction method in duplicates (Bligh and Dyer, 1959). The viral supernatant $(0.6 \mathrm{~L})$ was filtered at $0.45 \mu \mathrm{m}$ and the viral vector was concentrated by ultra-centrifugation at $100,000 \mathrm{~g}$ for $90 \mathrm{~min}$ at $4^{\circ} \mathrm{C}$ in a $45 \mathrm{Ti}$ Beckman rotor. The pelleted virus was ressuspended in PBS pH 7.2 (Gibco) and purified by ultra-centrifugation in a 20\% (w/v) sucrose solution (Merck) at $200,000 \mathrm{~g}$ for $120 \mathrm{~min}$ at $4^{\circ} \mathrm{C}$ in a $90 \mathrm{Ti}$ Beckman rotor. The purified vector was used for the lipid extraction (Bligh and Dyer, 1959). The experiment was repeated at least twice using independent cell batches.

\section{Total Phospholipids and Cholesterol Quantification}

Concentration of total phospholipids was determined by a colorimetric assay based on complex formation between ammonium ferrothiocyanate and the phospholipid (Stewart, 1980); cholesterol was determined by an enzymatic assay using the Cholesterol 20 Sigma Diagnostics Kit (352-20) under the manufacturer's instructions.

\section{Analysis of Phospholipids by Electrospray Ionisation Tandem Mass Spectrometry}

ESI mass spectra were acquired on an ion trap mass analyser (Brucker-Daltonics, Esquire 3000+) equipped with an electrospray interface. The detector of the instrument is a conversion dynode-based system operable until $10 \mathrm{KV}$. The effective mass range used varied from 50 to $2000 \mathrm{~m} / \mathrm{z}$.

For all experiments, both the electrospray needle and the skimmer were operated at ground potential, whereas the electrospray chamber and metalized entrance of the glass capillary were operated at $-4 \mathrm{kV}$ in the positive ion mode and at $+4 \mathrm{kV}$ in the negative ion mode. A positive or negative 90 $\mathrm{V}$ potential was applied to the metalized exit of the glass capillary for positive or negative ion spectra, respectively. A separate positive or negative $175 \mathrm{~V}$ potential was placed on the tube lens for acquisition of positive or negative ions, respectively. The temperature of the nitrogen drying gas as it entered the electrospray chamber was set at $265^{\circ} \mathrm{C}$ and the drying gas was held at a constant pressure of $15 \mathrm{psi}$ and a nebulizer flux of $4 \mathrm{~L} / \mathrm{min}$. All the MS/MS experiments were done using helium as the collision gas and collision energies ranging from 1 to $2 \mathrm{~V}$.

Samples were dissolved in 1:2 chloroform/methanol and infused directly into the ESI chamber with a syringe pump at a flow rate of $120 \mu \mathrm{L} / \mathrm{h}$.

The identification of the different phospholipid peaks was made by the molecular mass value determined and by comparison of their fragmentation patterns with those from commercial standards.

\section{RESULTS}

\section{Effect of Osmolality on the Retroviral Vector Production}

The effect of the cell culture medium osmolality on the production of MoMLV retroviral vectors was assessed by the use of increasing concentrations of ionic and non-ionic osmolytes. The sodium chloride salt was used as ionic osmotic agent and the non-metabolised sorbitol was added to the medium as a non-ionic osmotic agent. A second strategy to increase the medium osmolality was the use of the alternative sugar source fructose (instead of glucose) at high concentrations. It originates low amounts of lactate and has been shown previously to enhance the vector production and stability at high concentrations (Coroadinha et al., 2006; Gény-Fiamma et al., 2004; Merten et al., 2001b).

Figure 1 depicts $24 \mathrm{~h}$ production titers obtained for the different media containing different osmolytes and osmolalities, after a 4 day period of cell adaptation to the medium used. Sodium chloride addition hampered the production of retroviral vectors when compared with standard $25 \mathrm{mM}$ glucose medium $(325 \mathrm{mOsm} / \mathrm{kg})$ : higher osmolalities resulted in lower vector titers. Sorbitol, as an osmotic agent, improved the infectious vector titer at osmolalities of 410 and $450 \mathrm{mOsm} / \mathrm{kg}$; a decrease in the titer was observed when the concentration of sorbitol was raised to $500 \mathrm{mOsm} / \mathrm{kg}$ which, should be related to the lower cell yield then obtained (Table I). For fructose medium an increment in the

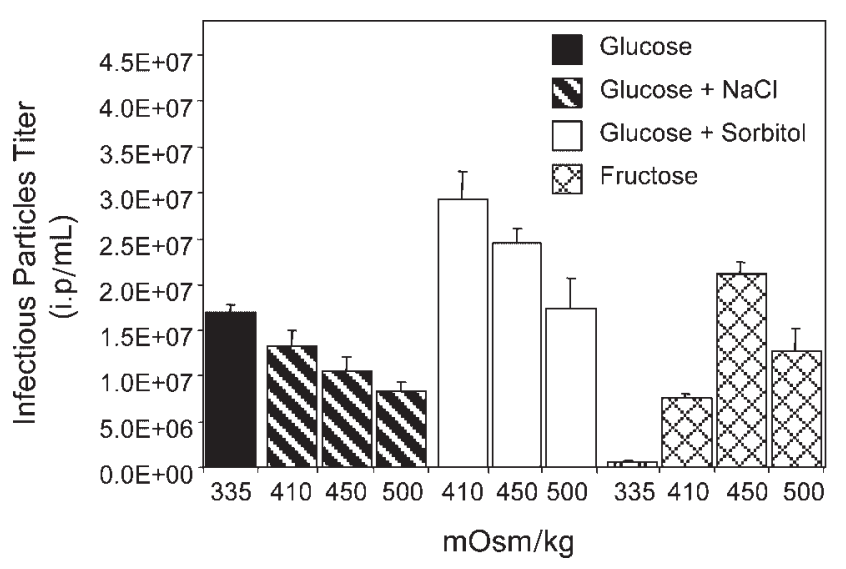

Figure 1. Effect of different medium osmolalities in the production of infectious vector titers. Error bars represent standard error of the mean, $n=8$. 
Table I. Osmolality effect upon cell density, cell volume and cell productivities.

\begin{tabular}{lcccc}
\hline Medium & $\begin{array}{c}\text { Osmolality } \\
(\mathrm{mOsm} / \mathrm{kg})\end{array}$ & $\begin{array}{c}\text { Viable cells } \\
\left(10^{5} \text { cells/cm }\right.\end{array}$ & $\begin{array}{c}\text { Mean cell volume } \\
(\mathrm{pL})\end{array}$ & $\begin{array}{c}\text { Cell productivity } \\
\text { (i.p./cells } \mathrm{s})\end{array}$ \\
\hline Glucose $25 \mathrm{mM}$ & 335 & $5.8 \pm 0.1$ & $3.5 \pm 0.1$ & $0.38 \pm 0.03$ \\
Glucose $25 \mathrm{mM}+\mathrm{NaCl}$ & 410 & $5.3 \pm 0.1$ & $4.2 \pm 0.1$ & $0.20 \pm 0.02$ \\
& 450 & $3.04 \pm 0.04$ & $5.2 \pm 0.1$ & $0.22 \pm 0.02$ \\
Glucose $25 \mathrm{mM}+$ Sorbitol & 500 & $1.24 \pm 0.01$ & $7.1 \pm 0.2$ & $0.43 \pm 0.05$ \\
& 410 & $3.81 \pm 0.07$ & $4.4 \pm 0.1$ & $0.70 \pm 0.07$ \\
Fructose $25 \mathrm{mM}$ & 450 & $2.03 \pm 0.04$ & $5.0 \pm 0.1$ & $0.90 \pm 0.09$ \\
Fructose $83 \mathrm{mM}$ & 500 & $0.83 \pm 0.01$ & $6.9 \pm 0.2$ & $1.5 \pm 0.2$ \\
Fructose $140 \mathrm{mM}$ & 335 & $0.73 \pm 0.01$ & $4.5 \pm 0.1$ & $0.11 \pm 0.01$ \\
Fructose $184 \mathrm{mM}$ & 410 & $1.21 \pm 0.02$ & $5.9 \pm 0.1$ & $0.52 \pm 0.05$ \\
\hline
\end{tabular}

Each value represents the average and standard error of the mean, $n=8$.

production titer was only observed at $450 \mathrm{mOsm} / \mathrm{kg}$. Although the cell productivities in fructose were similar to the ones obtained for sorbitol at the same osmolalities, the cell yields and thus the volumetric titers were lower (Table I). In Table I the cell densities reached at the time of harvesting are presented; in all cases and for all osmolytes used a decrease in the cell yield was observed, coherent with the decrease in cell growth that has been observed for animal cell cultures grown under prolonged high osmotic pressures (Cherlet and Marc, 1999; Clegg et al., 1986; Lee and Lee, 2000; Takagi et al., 2000). The use of fructose at $25 \mathrm{mM}$ resulted in an eightfold decrease in the cell yield when compared with the use of $25 \mathrm{mM}$ of glucose. When fructose was used at 83 and $140 \mathrm{mM}$ (corresponding to 410 and $450 \mathrm{mOsm} / \mathrm{kg}$, respectively) the cell yield slightly augmented to 1.21 and $1.41 \times 10^{5} \mathrm{cells} / \mathrm{cm}^{2}$, respectively. Despite of these observed increments, the cell yield obtained using fructose medium was always lower than the cell yields obtained at the corresponding osmolalities when glucose was used as the sugar source. This was due to the deficient uptake of fructose that was nevertheless enhanced at increasing concentrations (Coroadinha et al., 2005). At $500 \mathrm{mOsm} / \mathrm{kg}$ the enhancement in fructose uptake effect was overcome by the osmotic pressure effect and the cell yield was the lowest obtained. Another common effect observed in animal cell cultures when grown under hyperosmotic conditions is cell swelling; thus, Table I presents the mean cell volume, an increase in cell volume being observed as the medium osmolality increases for all osmolytes.

\section{Effect of Osmolality in Retroviral Vector Stability}

The impact of the production medium osmolality on the infectious retroviral vector stability was assessed by running stability assays in medium without any sugar source or osmolytes. This was performed in order to obtain the inactivation decay kinetics characteristic of the viral vector eliminating possible osmolyte chemical stabilizing effects per se. Figure 2A shows that the osmotic pressure imposed by sodium chloride improved the vector stability, slowing the rate of viral decay; this increase in the vector stability augments with the medium osmolality. The differences between 335 and $410 \mathrm{mOsm}$ were the sharpest, followed by the differences between 410 and $450 \mathrm{mOsm} / \mathrm{kg}$; the differences between 450 and $500 \mathrm{mOsm} / \mathrm{kg}$ are negligible. Likewise, when sorbitol was used as an osmotic agent the retrovirus stability increased as the medium osmolality increased; again the differences between 450 and $500 \mathrm{mOsm} /$ $\mathrm{kg}$ of sorbitol were very small (Fig. 2B). Similar results were observed for fructose (Fig. 2C), thus indicating that between 450 and $500 \mathrm{mOsm} / \mathrm{kg}$ a maximum value for the vector halflife was achieved. Table II summarises the effect of the production media on the vector half-life. The half-life of the vector proved to be dependent on the osmolality $(P<0.05)$ of the production medium although it is not dependent on the type of osmolyte used $(P>0.05)$.

\section{Effect of Osmolality in the Phospholipids and Cholesterol Composition of the Producer Cells and Retroviral Vectors}

From the results shown above, retroviral production at $450 \mathrm{mOsm} / \mathrm{kg}$ of sorbitol or fructose presented substantial improvements in vector stability while maintaining high production titers; thus, these conditions were chosen to analyse the cholesterol and phospholipid composition, and to compare with the standard glucose production conditions ( $335 \mathrm{mOsm} / \mathrm{kg}$ ). The osmotic pressure imposed either by high fructose concentration or by sorbitol led to differences in the cholesterol/phospholipids ratio $(\mathrm{C} / \mathrm{P})$ in the cells and in the vector composition (Table III). In cells the C/P ratio was decreased by $40 \%$ when osmolality was augmented from 335 (glucose $25 \mathrm{mM}$ ) to $450 \mathrm{mOsm} / \mathrm{kg}$ for either fructose or sorbitol whereas at $410 \mathrm{mOsm} / \mathrm{kg}$ the $\mathrm{C} / \mathrm{P}$ ratio for cells was $0.14-0.15$ (data not shown). For the viral vector, the production conditions at $450 \mathrm{mOsm} / \mathrm{kg}$ also led to a $40 \%$ decrease in the $\mathrm{C} / \mathrm{P}$ ratio when comparing with the standard $25 \mathrm{mM}$ of glucose production condition (335 mOsm $/ \mathrm{kg}$ ).

To obtain further information on the phospholipid composition a mass spectrometry analysis was performed for the cellular and viral lipid extractions. As can be seen in 
A

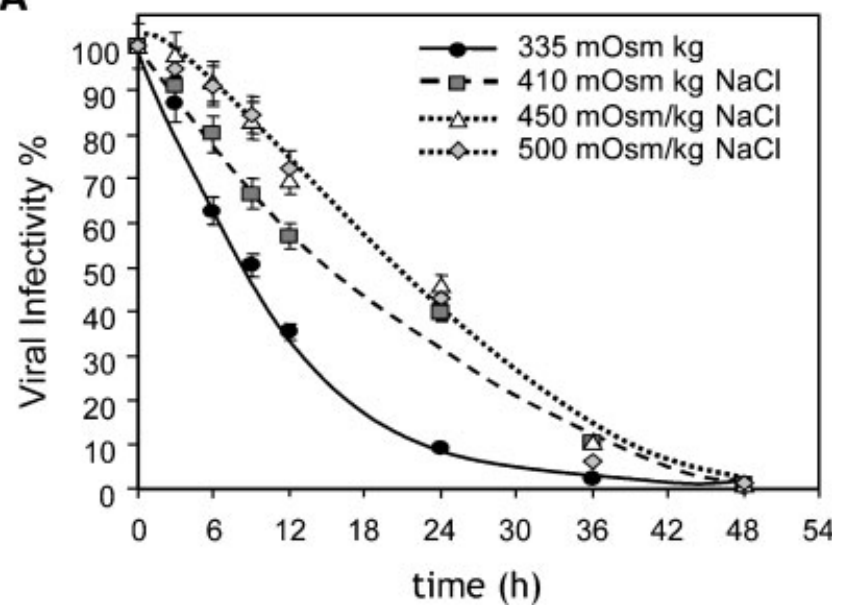

B

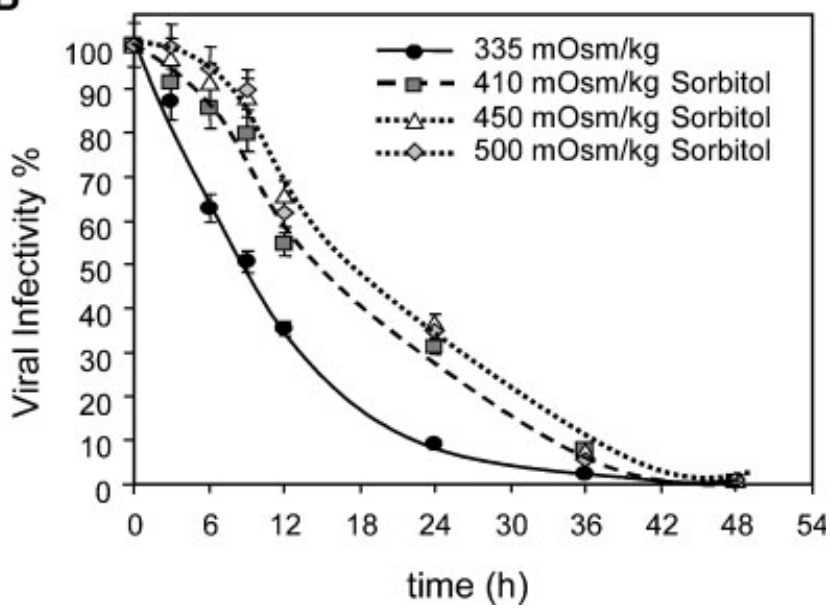

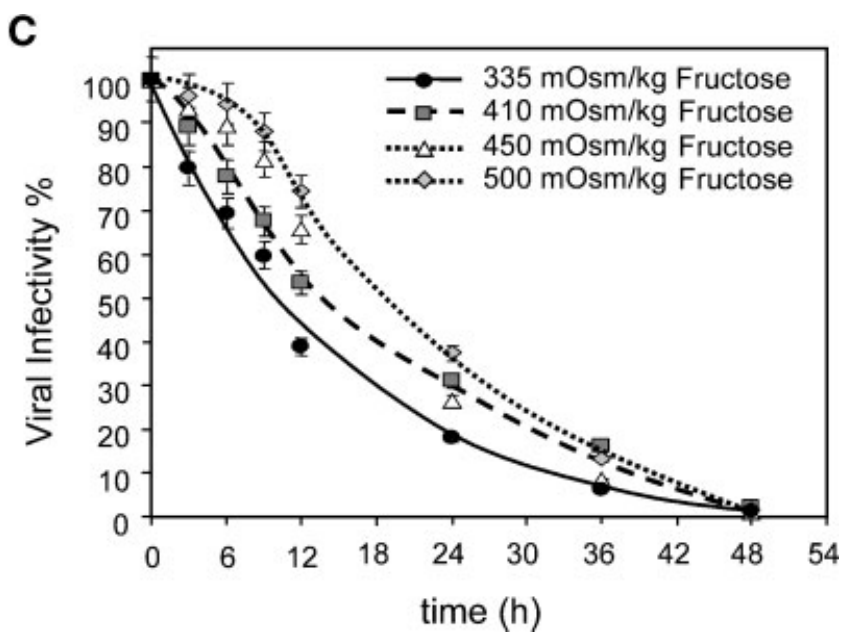

Figure 2. Decay kinetics of infectious vector during incubation at $37^{\circ} \mathrm{C}$ in medium without any osmotic agent or sugar source. The virus were originally produced in (A) medium with different osmolalities using $\mathrm{NaCl}$ as osmotic agent and glucose at 25 mM as sugar source (B) medium with different osmolalities using sorbitol as osmotic agent and glucose at $25 \mathrm{mM}$ as sugar source and (C) medium with different osmolalities using fructose, both as sugar source and osmotic agent, at different concentrations (, $335 \mathrm{mOsm} / \mathrm{kg} ; \boldsymbol{\square}, 410 \mathrm{mOsm} / \mathrm{kg} ; \triangle, 450 \mathrm{mOsm} / \mathrm{kg}$ and $\bullet 500 \mathrm{mOsm} / \mathrm{kg}$ ). Error bars represent standard deviation, $n=4$.

Figure 3, Te Fly A7 cell line did not present a great diversity of phospholipids, few phospholipids being major constituents, namely those derived from phosphatidylethanolamine (PE) and phosphatidylcholine (PC). Since the goal of this work was to verify if there were changes in the phospholipid composition that could influence the viral membrane rigidity,

Table II. Osmolality effect upon the vector half-life.

\begin{tabular}{lccc}
\hline $\begin{array}{l}\text { Osmolality } \\
(\mathrm{mOsm} / \mathrm{kg})\end{array}$ & $\mathrm{NaCl}^{\mathrm{a}}$ & $\begin{array}{c}\text { Half-life (h) } \\
\text { sorbitol }^{\mathrm{a}}\end{array}$ & Fructose \\
\hline 335 & $8.0 \pm 0.7$ & $8.0 \pm 0.7$ & $9.9 \pm 0.7$ \\
410 & $14 \pm 1$ & $13 \pm 2$ & $13.4 \pm 0.8$ \\
450 & $16 \pm 2$ & $15 \pm 2$ & $14 \pm 2$ \\
500 & $16 \pm 2$ & $14 \pm 2$ & $16 \pm 2$ \\
\hline
\end{tabular}

${ }^{\mathrm{a}}$ Glucose was used as sugar source.

The errors correspond to a $95 \%$ confidence interval obtained in the fittings of equation $V / V_{0}=\mathrm{e}^{-\gamma t}$ Le Doux et al. (1999).

Significance between groups was determined by a two-way ANOVA The osmolality groups $335,410,450$ and $500 \mathrm{mOsm} / \mathrm{kg}$ showed to be significantly different $(P<0.0004)$. The differences obtained between $\mathrm{NaCl}$, Sorbitol and Fructose osmolytes were not significant. only the phospholipids presenting a contribution higher than $5 \%$ were considered. The two major species detected in negative mode in mass spectrometry were both ether linked PEs (Fig. 3A) and the major phospholipids detected in positive mode were PC (Fig. 3B); at lower percentages phosphatidylinositol (PI) and phosphatidylserine (PS) were

Table III. Osmolality effect upon cholesterol/phospholipid molar ratio on cells and retroviral vectors.

\begin{tabular}{lccc}
\hline & & \multicolumn{2}{c}{$\begin{array}{c}\text { Cholesterol/phospholipids } \\
\text { molar ratio }\end{array}$} \\
\cline { 3 - 4 } Medium & $\begin{array}{c}\text { Osmolality } \\
\text { (mOsm/kg) }\end{array}$ & Cells & Vector \\
\hline Glucose $25 \mathrm{mM}$ & 335 & $0.21 \pm 0.01$ & $0.53 \pm 0.03$ \\
Glucose $25 \mathrm{mM}+$ Sorbitol & 450 & $0.12 \pm 0.01$ & $0.33 \pm 0.01$ \\
Fructose $140 \mathrm{mM}$ & 450 & $0.12 \pm 0.01$ & $0.30 \pm 0.01$ \\
\hline
\end{tabular}

Each value represents the average and standard error of the mean, $n=4$ for cell samples and $n=2$ for virus samples. 
A
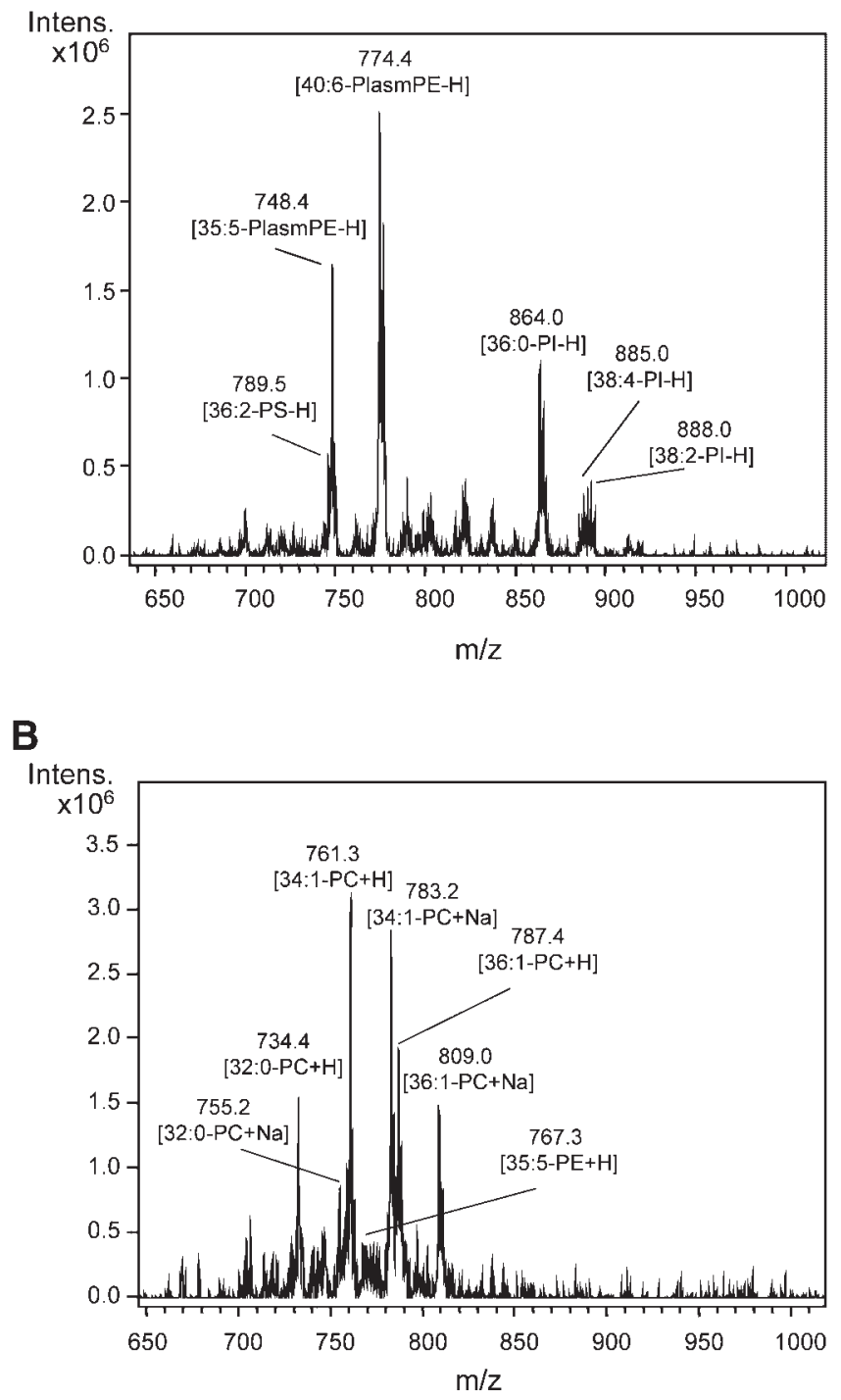

Figure 3. ESI-MS from total lipid extracts analysis of the producer cell grown in standard $25 \mathrm{mM}$ of glucose. A: Negative ion mass spectrum. B: Positive ion mass spectrum. Plasmalogens (plasm) refers to lipid species with an alkyl or alkenyl ether-linked chain in the sn-1 position of the glycerol moiety.

also detected. Sphingomyelin (SM), a phospholipid commonly found in lipid rafts and known to confer rigidity to the membrane, was not detected in the cells or virus indicating it should not affect significantly the membrane rigidity of the vectors studied in this work. Different fatty acid compositions and saturation levels were observed, and this could affect the vector membrane fluidity. Generally, the fatty acid length ranged from 16 to 22 carbons while the saturation of the fatty acids varied from absence of double bonds to three double bounds (Table IV). No effect of osmolality or sugar type used was observed in the composition of the phospholipids. The order of relative abundance of each phospholipid type and species was maintained except for 36:2-PS and 38:4-PI that slightly increased in the media at $450 \mathrm{mOsm} / \mathrm{kg}$. The percentages of contribution of each phospholipid species was nearly the same for the different production media tested.

The major phospholipids found in the viral vector composition were the same present in the producer cell, although their relative abundance was not the same. In general the viral vector had a lower relative abundance of 36:1-PC and a higher relative abundance of 32:0-PC (with an exception for the sorbitol experiment) this being the second most abundant phospholipid on the vector detected in positive mode. Also the 36:2-PS content increased for all vectors produced herein (Table IV). In terms of osmolality there was no obvious effect in the vectors. For the sorbitol as an osmolyte there was a significant drop on 38:5-PE and 36:0PI, compensated by higher abundances of 38:4-PI and 38:2PI, thus augmenting the saturation of PI fatty acids. For the vectors produced in fructose there was a lower drop on 38:5$\mathrm{PE}$ and 36:0-PI comparatively to glucose, compensated by a very high increment on 36:2-PS. Therefore, in addition to the osmolality effect, a metabolic effect of fructose on phospholipids may exist.

\section{DISCUSSION}

In this work the effect of high osmotic pressures was tested on Te Fly A7, a human cell line producing MoMLV derived retroviral vectors.

Sodium chloride, sorbitol, and fructose, at osmolalities above $410 \mathrm{mOsm} / \mathrm{kg}$, efficiently induced the cell into osmotic stress, identified by cell swelling and reduced cell growth (Table I), commonly observed effects in animal cell lines.

The most important conclusion from this work was, as hypothesised, that increased osmotic pressures enhance the infectious stability of the viral vector, independently of the osmolyte used. An important increment in the cell-specific infectious particles productivity was also observed when sorbitol and fructose were used (Table I) corroborating what is commonly observed in the production of recombinant proteins, namely antibody production (Cherlet and Marc, 1999; Lee and Lee, 2000). The use of $\mathrm{NaCl}$ as osmotic agent resulted in a decrease of the cell-specific infectious particles productivity, which might be explained by interference of $\mathrm{Na}^{+}$or $\mathrm{Cl}^{-}$ions with viral enzymes or proteins important for the virus production and assembly. Inhibition of the MoMLV Gag precursor protein $\left(\mathrm{Pr}^{\mathrm{gag}}\right.$ ) cleavage by $\mathrm{NaCl}$ has been reported, for salt concentrations within the range used in this work, resulting in an increase in immature particles (Yoshinaka and Luftig, 1981).

The increment of both vector stability and cell productivity resulted in higher infectious titers when sorbitol or fructose were used at osmolalities of $450 \mathrm{mOsm} / \mathrm{kg}$ (Fig. 1) even though a reduction in cell yield was observed.

Figure 2 and Table I strongly confirm that, independently of the osmotic agent used, the stability of the vector increased with increasing osmotic pressures; the enhancement of stability reaches a maximum near $450 \mathrm{mOsm} / \mathrm{kg}$. The increments verified in the vector stability were not due to chemical protective effects per se: (i) because the infectivity 
Table IV. Molecular species composition of the major glycerophospholipids classes in the producer cells and in the retroviral vector.

\begin{tabular}{|c|c|c|c|c|c|c|c|}
\hline \multirow{3}{*}{$\begin{array}{l}\text { Molecular } \\
\text { species }\end{array}$} & & \multicolumn{6}{|c|}{ Relative abundance $\%$} \\
\hline & & \multicolumn{2}{|c|}{ Glucose $335 \mathrm{mOsm} / \mathrm{kg}$} & \multicolumn{2}{|c|}{$\begin{array}{l}\text { Glucose }+ \text { Sorbitol } \\
450 \mathrm{mOsm} / \mathrm{kg}\end{array}$} & \multicolumn{2}{|c|}{ Fructose $450 \mathrm{mOsm} / \mathrm{kg}$} \\
\hline & & Cells & Vector & Cells & Vector & Cells & Vector \\
\hline \multicolumn{8}{|l|}{$[\mathrm{M}-\mathrm{H}]+$} \\
\hline \multirow[t]{3}{*}{$\mathrm{PC}$} & $34: 1$ & $100 \pm 6$ & $100 \pm 9$ & $100 \pm 0$ & $100 \pm 0$ & $100 \pm 0$ & $100 \pm 0$ \\
\hline & $36: 1$ & $59 \pm 3$ & $43 \pm 2$ & $46 \pm 5$ & $15 \pm 5$ & $51 \pm 5$ & $36 \pm 3$ \\
\hline & $32: 0$ & $25 \pm 3$ & $57 \pm 2$ & $33 \pm 2$ & $23 \pm 2$ & $34 \pm 1$ & $44 \pm 2$ \\
\hline $\begin{array}{l}\mathrm{PE} \\
{[\mathrm{M}-\mathrm{H}]-}\end{array}$ & $38: 5$ & $8 \pm 1$ & $7 \pm 1$ & $11 \pm 1$ & $8 \pm 1$ & $9 \pm 1$ & $16 \pm 2$ \\
\hline \multirow{2}{*}{$\begin{array}{l}\mathrm{PE}(\text { ether) } \\
\left(^{\mathrm{a}} \text { ether) }\right.\end{array}$} & $40: 6$ & $100 \pm 0$ & $100 \pm 0$ & $100 \pm 0$ & $100 \pm 0$ & $100 \pm 0$ & $100 \pm 0$ \\
\hline & $38: 5$ & $62 \pm 4$ & $69 \pm 5$ & $72 \pm 1$ & $39 \pm 3$ & $53 \pm 17$ & $57 \pm 7$ \\
\hline \multirow[t]{3}{*}{ PI } & $36: 0$ & $45 \pm 11$ & $57 \pm 3$ & $48 \pm 1$ & $25 \pm 3$ & $46 \pm 11$ & $40 \pm 3$ \\
\hline & $38: 4$ & $18 \pm 5$ & $30 \pm 4$ & $29 \pm 7$ & $44 \pm 2$ & $32 \pm 2$ & $23 \pm 1$ \\
\hline & $38: 2$ & $17 \pm 2$ & $15 \pm 1$ & $17 \pm 3$ & $26 \pm 1$ & $18 \pm 3$ & $13 \pm 1$ \\
\hline PS & $36: 2$ & $16 \pm 2$ & $22 \pm 2$ & $20 \pm 1$ & $22 \pm 1$ & $23 \pm 0$ & $60 \pm 10$ \\
\hline
\end{tabular}

${ }^{\mathrm{a}}$ Ether lipid refers to a species with an alkyl or alkenyl ether-linked chain in the sn-1 position of the glycerol moiety also denominated plasmalogens (plasm).

Each value represents the average and standard error of the mean, $n=4$ for cell samples and $n=2$ for vector samples.

kinetics assays were performed in diluted medium without osmotic agents to ensure that the intrinsic vector stability was being measured and (ii) because it was previously demonstrated that, in the range of sugar concentrations used, there was no chemical stabilizing influence (Coroadinha et al., 2006). The biophysical explanation for this viral stability enhancement can be obtained from the viral membrane lipid composition. The fact that the producer cell lines were subjected to high osmotic pressures showing higher cell volumes at higher osmolalities suggests that the cytoplasmatic membrane composition could have been rearranged and its fluidity increased, as a result of cell adaptation to the osmotic stress. The C/P molar ratios presented in Table III confirms that the osmotic pressure affects the cholesterol and phospholipid composition in both producer cells and viral vector: both the cell and vector $\mathrm{C} / \mathrm{P}$ molar ratios decreased $40 \%$ as the osmolality increased to $450 \mathrm{mOsm} / \mathrm{kg}$. The virus presented higher cholesterol content than the cells, as also observed in HIV-1 virus (Aloia et al., 1993), as they assemble and bud from the cells in membrane cholesterol rich microdomains (lipid rafts). A reduction in cholesterol content from $35 \%$ to $25 \%$ occurred in the viral membrane when osmolality was raised from standard 335 to $450 \mathrm{mOsm} /$ $\mathrm{kg}$, originating a more fluid vector membrane; this is coherent with the higher vector stability obtained at higher osmolalities and with the results described by Beer et al. (2003) and Cruz et al. (2005) where the more stable retroviral vectors had a more fluid membrane and a lower cholesterol content.

The fluidity of the membrane is also dependent upon the type of phospholipids and their fatty acids length and double bond saturation; in particular, SM, present at high percentage in lipid rafts, where enveloped viruses bud from the cell, confers rigidity to the membrane (Guyader et al., 2002;
Suomalainen, 2002). Since SM was undetected herein, neither being present in the cells nor in the virus, it does not contribute to vector membrane rigidity in this case. Concerning the fatty acid saturation and length, as analysed by MS, there were no significant differences in producer cell lipid composition when different osmolality media were used. In the viral vectors some changes in the phospholipid species were observed although they do not seem sufficient to support the hypothesis of higher fatty acid saturation or lower fatty acid length that would lead to substantially higher membrane fluidity. Therefore the effect of osmolality observed in the $\mathrm{C} / \mathrm{P}$ ratios in both the producer cell line and the viral vector membrane should constitute the key explanation for the enhanced vector stabilities observed.

From the work presented herein osmolality was proven to be an important retroviral production parameter, its optimisation in production leading to higher retroviral vector titers and quality. Furthermore, an irrefutable relationship between vector membrane composition and vector stability has been confirmed and explained, allowing improved production and new optimisation strategies to be explored.

\section{References}

Aloia RC, Tian H, Jensen FC. 1993. Lipid composition and fluidity of the human immunodeficiency virus envelope and host cell plasma membranes. Proc Natl Acad Sci USA 90(11):5181-5185.

Andreadis ST, Roth CM, Le Doux JM, Morgan JR, Yarmush ML. 1999. Large-scale processing of recombinant retroviruses for gene therapy. Biotechnol Prog 15(1):1-11.

Beer C, Meyer A, Muller K, Wirth M. 2003. The temperature stability of mouse retroviruses depends on the cholesterol levels of viral lipid shell and cellular plasma membrane. Virology 308(1):137-146. 
Bligh EG, Dyer WJ. 1959. A rapid method of total lipid extraction and purification. Can J Biochem Physiol 37(8):911-917.

Cherlet M, Marc A. 1999. Hybridoma cell behaviour in continuous culture under hyperosmotic stress. Cytotechnology 29:71-84.

Clegg J, Gallo J, Gordon E. 1986. Some structural, biochemical and biophysical characteristics of L-929 cells growing in the presence of hyperosmotic sorbitol concentrations. Exp Cell Res 163(1):35-46.

Coroadinha AS, Ribeiro J, Roldão A, Cruz PE, Alves PM, Merten O-W, Carrondo MJT. 2006. Effect of medium sugar source on the production of retroviral vectors for gene therapy. Biotech Bioeng (in press).

Cosset FL, Takeuchi Y, Battini JL, Weiss RA, Collins MK. 1995. High-titer packaging cells producing recombinant retroviruses resistant to human serum. J Virol 69(12):7430-7436.

Cruz PE, Almeida JS, Murphy PN, Moreira JL, Carrondo MJ. 2000. Modeling retrovirus production for gene therapy 1. Determination Of optimal bioreaction mode and harvest strategy. Biotechnol Prog 16(2): 213-221.

Cruz PE, Carmo M, Coroadinha AS, Bengala A, Gonçalves D, Teixeira M, Merten O-W, Genny-Fiamma C, Carrondo MJT. 2005. Retroviral vector stability: Inactivation kinetics and membrane properties. In: Gòdia F, Fussenegger M, editors. Animal cell technology meets genomics. Dordrecht, NL: Springer. pp 303-308.

Davis JL, Witt RM, Gross PR, Hokanson CA, Jungles S, Cohen LK, Danos O, Spratt SK. 1997. Retroviral particles produced from a stable humanderived packaging cell line transduce target cells with very high efficiencies. Hum Gene Ther 8(12):1459-1467.

Dunbar C, Kohn D. 1996. Retroviral mediated transfer of the cDNA for human glucocerebrosidase into hematopoietic stem cells of patients with Gaucher disease. A phase I study. Hum Gene Ther 7(2):231-253.

Guyader M, Kiyokawa E, Abrami L, Turelli P, Trono D. 2002. Role for human immunodeficiency virus type 1 membrane cholesterol in viral internalization. J Virol 76(20):10356-10364.

Gény-Fiamma C, Millot L, Rocca C, Danos O, Merten O-W. 2004. Optimization of the production of retroviral vectors: Influence of the sugar source. In: Yagasaki K, Miura Y, Hattori M, Nomura Y, editors. Animal cell tecnhology: Basic and applied aspects. Dordrecht: Kluwer Academic Publisher. pp 89-97.

Harada S, Yusa K, Monde K, Akaike T, Maeda Y. 2005. Influence of membrane fluidity on human immunodeficiency virus type 1 entry. Biochem Biophys Res Commun 329(2):480-486.

Higashikawa F, Chang L. 2001. Kinetic analyses of stability of simple and complex retroviral vectors. Virology 280(1):124-131.

Kim NS, Lee GM. 2002. Response of recombinant Chinese hamster ovary cells to hyperosmotic pressure: Effect of $\mathrm{Bcl}-2$ overexpression. J Biotechnol 95(3):237-248.

Le Doux JM, Davis HE, Morgan JR, Yarmush ML. 1999. Kinetics of retrovirus production and decay. Biotechnol Bioeng 63(6):654-662.

Lee MS, Lee GM. 2000. Hyperosmotic pressure enhances immunoglobulin transcription rates and secretion rates of $\mathrm{KR} 12 \mathrm{H}-2$ transfectoma. Biotechnol Bioeng 68(3):260-268.
Lee SG, Kim S, Robbins PD, Kim BG. 1996. Optimization of environmental factors for the production and handling of recombinant retrovirus. Appl Microbiol Biotechnol 45(4):477-483.

McTaggart S, Al-Rubeai M. 2000. Effects of culture parameters on the production of retroviral vectors by a human packaging cell line. Biotechnol Prog 16(5):859-865.

Merten OW. 2004. State-of-the-art of the production of retroviral vectors. J Gene Med 6(Suppl 1):S105-S124.

Merten OW, Cruz PE, Rochette C, Geny-Fiamma C, Bouquet C, Goncalves D, Danos O, Carrondo MJ. 2001a. Comparison of different bioreactor systems for the production of high titer retroviral vectors. Biotechnol Prog 17(2):326-335.

Merten OW, Landric L, Danos O. 2001b. Influence of the metabolic state of packaging cells on retroviral vector production. In: Merten OW, Mattanovich D, Lang C, Larsson G, Neubauer P, Porro D, Postma P, Teixeira de Mattos J, Cole J, editors. Recombinant protein production with prokaryotic and eukaryotic cells. A comparative view on host physiology. Dordrecht/NL: Kluwer Academic Press. pp 301-316.

Morita S, Kojima T, Kitamura T. 2000. Plat-E: An efficient and stable system for transient packaging of retroviruses. Gene Ther 7(12):1063-1066.

Mountain A. 2000. Gene therapy: The first decade. Trends Biotechnol 18(3):119-128.

Olejnik A, Grajek W, Marecik R. 2003. Effect of hyperosmolarity on recombinant protein productivity in baculovirus expression system. J Biotechnol 102(3):291-300.

Ory DS, Neugeboren BA, Mulligan RC. 1996. A stable human-derived packaging cell line for production of high titer retrovirus/vesicular stomatitis virus G pseudotypes. Proc Natl Acad Sci USA 93(21):1140011406.

Paul RW, Morris D, Hess BW, Dunn J, Overell RW. 1993. Increased viral titer through concentration of viral harvests from retroviral packaging lines. Hum Gene Ther 4(5):609-615.

Pizzato M, Merten OW, Blair ED, Takeuchi Y. 2001. Development of a suspension packaging cell line for production of high titre, serumresistant murine leukemia virus vectors. Gene Ther 8(10):737-745.

Stewart JC. 1980. Colorimetric determination of phospholipids with ammonium ferrothiocyanate. Anal Biochem 104(1):10-14.

Suomalainen M. 2002. Lipid rafts and assembly of enveloped viruses. Traffic 3(10):705-709.

Takagi M, Hayashi H, Yoshida T. 2000. The effect of osmolarity on metabolism and morphology in adhesion and suspension chinese hamster ovary cells producing tissue plasminogen activator. Cytotechnology 32(3):171-179.

Takagi M, Moriyama T, Yoshida T. 2001. Effects of shifts up and down in osmotic pressure on production of tissue plasminogen activator by Chinese hamster ovary cells in suspension. J Biosci Bioeng 91(5):509514.

Yoshinaka Y, Luftig RB. 1981. Inhibition of murine leukemia virus Pr65gag cleavage in vitro and in vivo by hypertonic medium. J Virol 37(3):10661070. 